\title{
Room Temperature Notification Device
}

\author{
Priyadharshini. SP, B.Mahalakshmi, Michael G
}

\begin{abstract}
This project is entitles as "ROOM TEMPERATURE NOTIFICATION DEVICE"is developed as an embedded system using arduino microcontroller and GSM(Global system for mobile communications)module this project helps us to prevent from fire accidents in server room server room.contains lot of devices such as hardware, racks,cabling system, power and UPS.if the temperature of a server room increases it will send notification to user. temperature sensor is used to notify the temperature of a server room.arduino is an open source hardware and software company, project and user community that design and manufactures single board microcontroller kits for building devices and interactive object that can sense and control or objects in the physical and digital world.GSM is used to send notification to user by sending message and making calls.LCD(Liquid Crystal Display)is used in this device to display the temperature.Buzzer produce sound indication in server room if the temperature increases by more than 40 degree.If the temperature increases it performs the following operationsTemperature increases from 30-35degree,it will send message to user Temperature increases from 35-40 degree,it will dial call to user Temperature increases more than 40 degree,it will produce sound in buzzer These operations are performed with the help of GSM module and microcontroller.
\end{abstract}

Keywords : Temperature sensor, Microcontroller, Server room temperature

\section{INTRODUCTION}

In the current generation peoples life full based on the computers.soit helps to improved the peoples knowledge. The computer Server room is plays an important role in IT infrastructure it is heart of the industries activity most of the organization to supports and organizes computer network or other IT related tasks.lot of problems accord inside of the rooms so the organization provides the lot of security to prevent the server room air conditioner it helps to maintain the correct levels of computer systems. Performance varies reasons to increase the room temperature[20],[22],[24]. major reasons for do not maintain properly for the room and minimum area to occupied more number of systems monitoring or notification of temperature from continuously .it will be reduced by the accidences Monitoring is one type of temperature recorder that monitors a temperature in a room and stores the data into a database. Over heating of server leads to fire accidents in server room reduced human loss in the previous paper to monitoring the temperature and it will send message to only the registered user. It only stored the temperature information cannot prevent the server room.this

Revised Manuscript Received on August 22, 2019.

Priyadharshini.SP, Department of Computer science and Engineering, Bharath Institute of Higher Education and Research, Chennai, Tamilnadu, India. Email: spriya07.cse@gmail.com

B.Mahalakshmi, Department of Computer science and Engineering, Bharath Institute of Higher Education and Research, Chennai, Tamilnadu, India. Email: mahalakshmibalaji304@gmail.com

Michael G, Department of Computer science and Engineering, Bharath Institute of Higher Education and Research, Chennai, Tamilnadu, India. Email: micgeo270479@gmail.com paper connect with four server room and send message to make a call to the register

user using GSM module visual basic 60 application and c language to used for the coding.

\section{LITERATURE SURVEY}

\section{A. A Web Based Temperature Monitoring System}

Authors: M. Kassim, M.N. Ismail and C.K.H. Che Ku Yahaya

Year: 2011

A Web Based Temperature Monitoring System that is utilized to constantly access and observing the temperature related data from the clients. in the current framework the temperature observing is that this model framework enabled the information to be checked whenever and anyplace from the internet[19],[21],[23]. There are two parts created in this venture paper equipment part working by utilized the temperature sensor board and programming part building utilizing the programming language compose a program in c coding the program can be transferred that microcontroller to make the visual essential 60 application to show the temperature and spare the temperature related data from the information as the database[13],[15],[17].

B.Remote temperature monitoring using L35 sensor and intimate android user via C2DM service

Authors: Yusuf Mulge

Year: 2013

Now a days the technology is increased in daily life, It send the message only to the registered user. Arduino Uno board and ethernet using a wireless sensor applications are used to prevent the fire accident in server room via using GPRS. It is always used to identifying the position[14],[16],[18].

\section{SYSTEM BLOCK DIAGRAM}

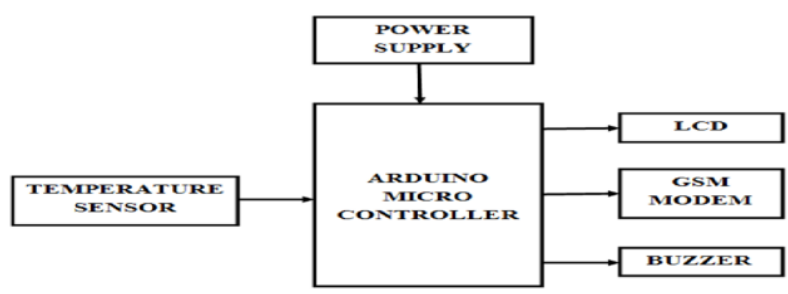

Figure - 1 Proposed Block Diagram

\section{WORKING METHODOLOGY}

This project is mainly designed to avoid fire accident in the server room.the power supply is given to microcontroller DHT11 temperature sensor detects the 
room temperature LCD to displays the actual temperature of a server room. GSM module is used to send message and make a calls to user .if the temperature increases it performs the following operations[25],[27],[29].

Temperature increases from 30-35 degree it will send the message to user

Temperature increases from 35-40 degree it will make a call to registered user

Temperature increase more than 40 degree it will produce sound in buzzer

These operations are performed with the help of GSM module and microcontroller[2],[4],[6].

\section{RESULTS}

\section{A. Module 1}

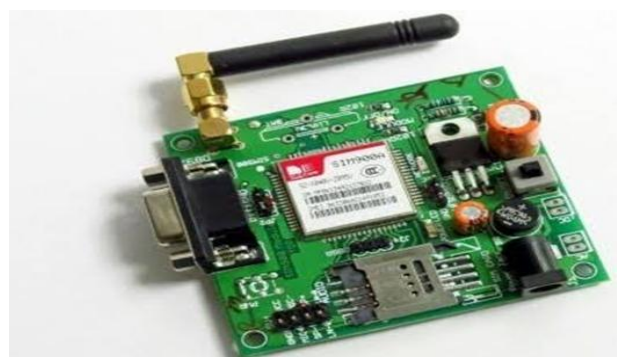

Figure - 1 GSM Module

\section{B. Module 2}

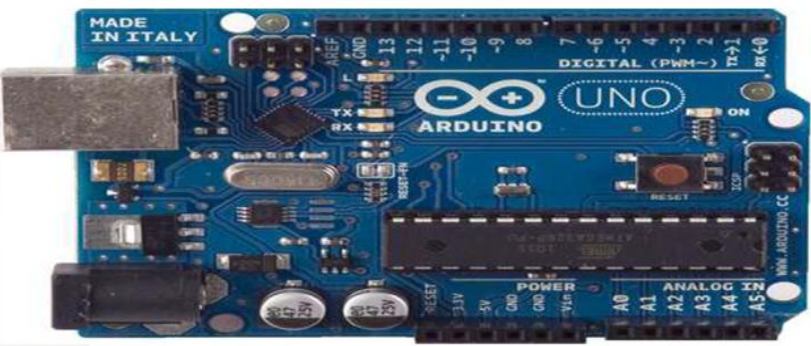

Figure - 2 Arduino Microcontroller

\section{Module 3}

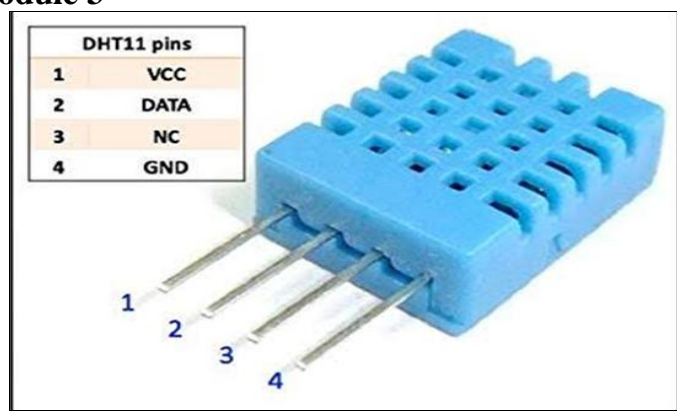

Figure - 3 Temperature Sensor

\section{Module 4}

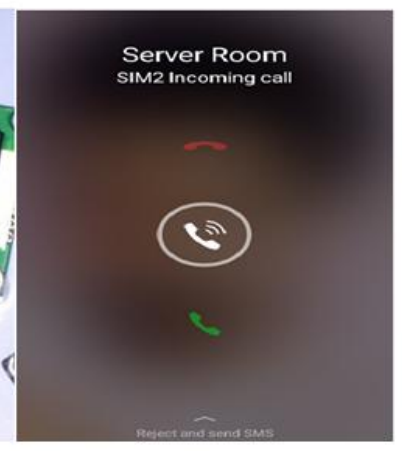

Figure - 6 Make a call to registered users

\section{G. Module 7}

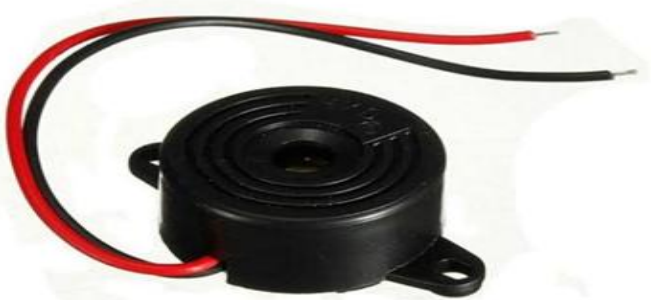

Figure - 7 Buzzer

\section{CONCLUSION}

The project was titled as "ROOM TEMPERATURE NOTIFICATION DEVIUCE" was developed to avoid fire accidents in server room. It is used to monitor the temperature of server room .It reduces the number of fire accidents .If the temperature increases it leads to fire accidents[26],[28],[30].The device is mainly implemented to overcome these problems

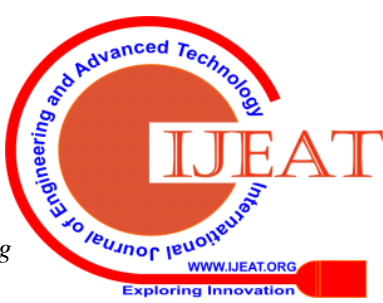


Easy to implement this method. It is very useful for companies and industries. LM35 temperature sensor produce accurate temperature and it is easily available.Arduino microcontroller is efficient module for sensing and controlling the operation of a device. GSM module is widely used for communication purposes.

\section{REFERENCES}

1. Gowri Sankaran, B., Karthik, B. \& Vijayaragavan, S.P. 2019, "Weight ward change region plummeting change for square based image huffman coding", International Journal of Innovative Technology and Exploring Engineering, vol. 8, no. 10, pp. 4313-4316.

2. Gowri Sankaran, B., Karthik, B. \& Vijayaragavan, S.P. 2019, "Image compression utilizing wavelet transform", International Journal of Innovative Technology and Exploring Engineering, vol. 8, no. 10, pp. 4305-4308.

3. Kandavel, N. \& Kumaravel, A. 2019, "Offloading computation for efficient energy in mobile cloud computing", International Journal of Innovative Technology and Exploring Engineering, vol. 8, no. 10, pp. 4317-4320.

4. Vinoth, V.V. \& Kanniga, E. 2019, "Reversible data hiding in encrypting images-an system", International Journal of Engineering and Advanced Technology, vol. 8, no. 6, pp. 3051-3053.

5. Selvapriya, B. \& Raghu, B. 2019, "Pseudocoloring of medical images: A research", International Journal of Engineering and Advanced Technology, vol. 8, no. 6, pp. 3712-3716.

6. Senthil Kumar, K. \& Muthukumaravel, A. 2019, "Bi-objective constrain and hybrid optimizer for the test case prioritization", International Journal of Engineering and Advanced Technology, vol. 8, no. 6, pp. 3436-3448.

7. Kavitha, G., Priya, N., Anuradha, C. \& Pothumani, S. 2019, "Read-write, peer-to-peer algorithms for the location-identity split", International Journal of Innovative Technology and Exploring Engineering, vol. 8, no. 9 Special Issue 3, pp. 445-447.

8. Kaliyamurthie, K.P., Michael, G., Anuratha, C. \& Sundaraj, B. 2019, "Certain improvements in alzheimer disease classification using novel fuzzy c means clustering for image segmentation", International Journal of Innovative Technology and Exploring Engineering, vol. 8, no. 9 Special Issue 3, pp. 599-604.

9. Kaliyamurthie, K.P., Sundarraj, B., Geo, A.V.A. \& Michael, G. 2019, "RIB: Analysis of I/O automata", International Journal of Innovative Technology and Exploring Engineering, vol. 8, no. 9 Special Issue 3, pp. 1019-1022.

10. Velvizhi, R., Rajabhushanam, C. \& Vidhya, S.R.S. 2019, "Opinion mining for travel route recommendation using Social Media Networks (Twitter)", International Journal of Innovative Technology and Exploring Engineering, vol. 8, no. 9 Special Issue 3, pp. 508-512.

11. Kavitha, R., Sangeetha, S. \& Varghese, A.G. 2019, "Human activity patterns in big data for healthcare applications", International Journal of Innovative Technology and Exploring Engineering, vol. 8, no. 9 Special Issue 3, pp. 1101-1103.

12. Pothumani, S., Anandam, A.K., Sharma, N. \& Franklin, S. 2019, "Extended VEOT framework - Implemented in a smart boutique", International Journal of Innovative Technology and Exploring Engineering, vol. 8, no. 9 Special Issue 3, pp. 762-767.

13. Kaliyamurthie, K.P., Michael, G., Krishnan, R.M.V. \& Sundarraj, B. 2019, "Pseudorandom techniques for the internet", International Journal of Innovative Technology and Exploring Engineering, vol. 8, no. 9 Special Issue 3, pp. 915-918.

14. Aravindasamy, R., Jeffrin Rajan, M., Rama, A. \& Kavitha, P. 2019, "Deep learning provisions in the matlab: Focus on CNN facility", International Journal of Innovative Technology and Exploring Engineering, vol. 8, no. 9 Special Issue 3, pp. 990-994.

15. Theivasigamani, S., Linda, M. \& Amudha, S. 2019, "Object sensing and its identification \& motion sensing", International Journal of Innovative Technology and Exploring Engineering, vol. 8, no. 9 Special Issue 3, pp. 545-549.

16. Mary Linda, I., Vimala, D. \& Shanmuga Priya, K. 2019, "A methodology for the emulation of IPv4", International Journal of Innovative Technology and Exploring Engineering, vol. 8, no. 9 Special Issue 3, pp. 848-852.

17. Velvizhi, R., Priya, D.J., Vimala, D. \& Linda, I.M. 2019, "Increased routing algorithm for mobile adhoc networks", International Journal of Innovative Technology and Exploring Engineering, vol. 8, no. 9 Special Issue 3, pp. 1606-1608.
18. Sangeetha, S., Anuradha, C. \& Priya, N. 2019, "DNS in real world", International Journal of Innovative Technology and Exploring Engineering, vol. 8, no. 9 Special Issue 3, pp. 937-940.

19. Geetha, C., Vimala, D. \& Priya, K.S. 2019, "Constructing multi-processors and spreadsheets with SKIVE", International Journal of Innovative Technology and Exploring Engineering, vol. 8, no. 9 Special Issue 3, pp. 516-519.

20. Yugendhar, K., Sugumar, V. \& Kavitha, P. 2019, "A novel method of univac using fuzzy logic", International Journal of Innovative Technology and Exploring Engineering, vol. 8, no. 9 Special Issue 3, pp. 435-437.

21. Kaliyamurthie, K.P., Michael, G., Elankavi, R. \& Jijo, S.A. 2019, "Implementing aggregate-key for sharing data in cloud environment using cryptographic encryption", International Journal of Innovative Technology and Exploring Engineering, vol. 8, no. 9 Special Issue 3, pp. 957-959.

22. Jeffrin Rajan, M., Aravindasamy, R., Kavitha, P. \& Rama, A. 2019, "A novel method of object orientation variation in $\mathrm{C}++$ and java", International Journal of Innovative Technology and Exploring Engineering, vol. 8, no. 9 Special Issue 3, pp. 708-710.

23. Nayak, R., Dinesh, S. \& Thirunavukkarasu, S. 2019, "A novel method improvement of rapid miner for the data mining applications", International Journal of Innovative Technology and Exploring Engineering, vol. 8, no. 9 Special Issue 3, pp. 457-460.

24. Sivaraman, K., Krishnan, R.M.V., Sundarraj, B. \& Sri Gowthem, S. 2019 "Network failure detection and diagnosis by analyzing syslog and SNS data: Applying big data analysis to network operations", International Journal of Innovative Technology and Exploring Engineering, vol. 8, no. 9 Special Issue 3, pp. 883-887.

25. Vimala, D., Linda, I.M. \& Priya, K.S. 2019, "Decoupling online algorithms from erasure coding in DNS", International Journal of Innovative Technology and Exploring Engineering, vol. 8, no. 9 Special Issue 3, pp. 950-953.

26. Rama, A., Kumaravel, A. \& Nalini, C. 2019, "Preprocessing medica images for classification using deep learning techniques", International Journal of Innovative Technology and Exploring Engineering, vol. 8, no. 9 Special Issue 3, pp. 711-716.

27. Sangeetha, S., Srividhya, S.R., Anita Davamani, K. \& Amudha, S. 2019 , "A procedure for avoid overrun error in universal synchronous asynchronous receiver transmitter (usart) by utilizing dummy join and interrupt latency method", International Journal of Innovative Technology and Exploring Engineering, vol. 8, no. 9 Special Issue 3, pp. 657-660.

28. Aravindasamy, R., Jeyapriya, D., Sundarajan, B. \& Sangeetha, S. 2019 "Data duplication in cloud for optimal performance and security", International Journal of Innovative Technology and Exploring Engineering, vol. 8, no. 9 Special Issue 3, pp. 1156-1158.

29. Aravindasamy, R., Jeffrin Rajan, M., Sugumar, V. \& Kavitha, P. 2019, "A novel method on developing superblocks and the transistor using apodryal", International Journal of Innovative Technology and Exploring Engineering, vol. 8, no. 9 Special Issue 3, pp. 982-985.

30. Sasikumar, C.S. \& Kumaravel, A. 2019, "E-learning attributes selection through rough set theory and data mining", International Journal of Innovative Technology and Exploring Engineering, vol. 8, no. 10, pp. 3920-3924.

\section{AUTHORS PROFILE}

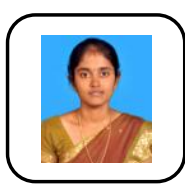

Priyadharshini.SP Assistant Professor, Department of Computer science and Engineering, Bharath Institute of Higher Education and Research, Chennai, India

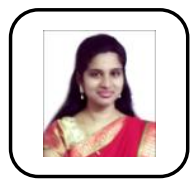

B.Mahalakshmi Assistant Professor, Department of Computer science and Engineering, Bharath Institute of Higher Education and Research, Chennai, India

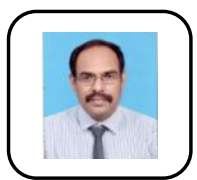

Michael G Professor, Department of Computer science and Engineering, Bharath Institute of Higher Education and Research, Chennai, India 